\title{
Research Square \\ Forest Fragmentation Slows the Decomposition of Coarse Woody Debris in a Subtropical Forest
}

\section{Chunsheng Wu}

Nanchang Institute of Technology

Cindy E. Prescott

University of British Columbia

\section{Chunjie Shu}

Nanchang Institute of Technology

\section{Baoyong Li}

Jiangxi Agricultural University

\section{Zhijian Zhang}

Jiangxi Agricultural University

\section{Hankun Wang}

Jiangxi Agricultural University

\section{Yi Zhang}

Lushan Nature Reserve of Jiangxi

Yuanqiu Liu ( $D$ liuyq404@163.com )

Jiangxi Agricultural University

G. Geoff Wang

Clemson University

\section{Research}

Keywords: Edge effects, Decomposition, CWD, Microbial community, Subtropical forests

Posted Date: May 25th, 2021

DOl: https://doi.org/10.21203/rs.3.rs-522038/v1

License: (c) (i) This work is licensed under a Creative Commons Attribution 4.0 International License.

Read Full License

Version of Record: A version of this preprint was published at Forest Science on September 17th, 2021. See the published version at https://doi.org/10.1093/forsci/fxab035. 
Title:

2 Forest fragmentation slows the decomposition of coarse woody debris in a subtropical

3 forest

4

5 Authors:

6 Chunsheng Wu ${ }^{\mathrm{a}, \mathrm{b}}$, Cindy E. Prescott ${ }^{\mathrm{c}}$, Chunjie Shu ${ }^{\mathrm{a}}$, Baoyong Li ${ }^{\mathrm{b}}$, Zhijian Zhang ${ }^{\mathrm{b}}$, Hankun Wang ${ }^{\mathrm{b}}$,

$7 \quad$ Yi Zhang ${ }^{\mathrm{d}}$, Yuanqiu Liu ${ }^{\mathrm{b}, \mathrm{d}^{*}}, \mathrm{G}$. Geoff Wang $\mathrm{g}^{\mathrm{b}, \mathrm{e}^{*}}$

8

9 Affiliation:

a Jiangxi Provincial Engineering Research Center For Seed-Breeding and Utilization of Camphor Trees, School of

Hydraulic and Ecological Engineering, Nanchang Institute of Technology, Tianxiang Rd. 289, Nanchang 330099,

P.R.China.

${ }^{\mathrm{b}}$ Key Laboratory of Silviculture, Co-Innovation Center of Jiangxi Typical Trees Cultivation and Utilization, College

of Forestry, Jiangxi Agricultural University, Zhimin Rd. 1101, Nanchang, 330045, P.R. China.

${ }^{\mathrm{c}}$ Faculty of Forestry, University of British Columbia,2424 Main Mall, Vancouver, BC, Canada.

${ }^{\mathrm{d}}$ Lushan Nature Reserve of Jiangxi (Lushan Mountain National Forest Ecological Station), Henan Rd. 600, Jiujiang

${ }^{\mathrm{e}}$ Department of Forestry and Environmental Conservation, Clemson University, Clemson, SC, 29634, USA.

*Co-correspondence authors: GGW: gwang@clemson.edu, 1-864-656-4864; YL: liuyq404@163.com, 
Abstract:

Forest fragmentation is increasing rapidly around the world, and edge effects caused by fragmented forests can influence ecosystem functions and ecological processes, including coarse woody debris (CWD) decomposition. Understanding the influencing mechanisms of edge effect on CWD decomposition is needed to assess the effects of forest fragmentation on C cycling and storage. We measured rates of mass loss of CWD of Cinnamomum camphora and Pinus taiwanensis over two years at two distances $(0-5 \mathrm{~m} v s .60 \mathrm{~m})$ from a forest edge at two altitudes (215 and $1400 \mathrm{~m}$ a.s.1.), in a subtropical forest. In addition, we determined the microbial community of each CWD and the soil beneath via phospholipid fatty acids (PLFAs). Mass loss of CWD $60 \mathrm{~m}$ from the forest edge was $>15 \%$ greater than that at the edge $(0-5 \mathrm{~m})$. Mass loss was positively correlated with the abundance of microbial community and moisture content of the decaying CWD. Distance from edge explained $17.4 \%$ of the total variation of the microbial abundance in CWD. The results indicated that the reduced abundance of microbial communities and moisture content at forest edges reduced rates of decomposition of CWD. Long-term experiments with more tree species and more forest types are needed to assess the edge effect's generality.

Keywords: Edge effects; Decomposition; CWD; Microbial community; Subtropical forests

\section{Introduction}

Forests around the world store a large amount of carbon (C) in soils, dead and living aboveground biomass (including coarse woody debris: CWD), which is regarded as a significant $\mathrm{C}$ sink (Pan et al., 2011). Understanding the factors that influence rates of $\mathrm{C}$ cycling processes in forests 
(including CWD decomposition) is necessary to quantify the role of global forests in the global C cycle (Pan et al., 2011; Intergovernmental Panel on Climate Change, 2014; Tang et al., 2018). Forest fragmentation due to natural and anthropogenic disturbances is a global phenomenon, affecting forest ecosystem functioning (Numata et al., 2010; FAO, 2010; Haddad et al., 2015; Barlow et al., 2016). Globally, nearly $20 \%$ of all forest area is situated within $100 \mathrm{~m}$ of a forest edge (Haddad et al., 2015). Forest edges have distinct microclimates from forest interiors, including lower soil moisture, lower humidity, increased light availability, and increased wind and rain impacts (Laurance and Yensen, 1991; Didham \& Ewers, 2012; Albiero-Júnior et al., 2020). These altered microclimatic conditions at forest edges can alter the decay rates of CWD. In a temperate forest in the United Kingdom, blocks of wood from European beech (Fagus sylvatica) placed at the forest edge lost mass at about half the rate of blocks placed $100 \mathrm{~m}$ within the forest (Crockatt \& Bebber, 2015). The slower mass loss was attributed to the lower humidity and moisture content of the decaying wood at the forest edge (Crockatt \& Bebber, 2015). In contrast, in a temperate forest in USA, Forrester et al. (2012) reported higher respiration rates from CWD in canopy gaps than under intact canopy.

Alterations in microclimatic conditions near forest edges may also influence soil microbial community composition. Previous studies have shown that the abundance of fungi strongly increased in response to changes in microclimate conditions due to edge effects (Boddy et al., 1989; Boddy, 2001; Castaño et al., 2018; van der Linde et al., 2018; Boeraeve et al., 2019). The fungal communities in soil and wood interact during all CWD decay phases (Mäkipää et al., 2017; Purahong et al., 2019; Wu et al., 2020, 2021), so changes in soil microbial communities due to edge effects could also alter fungal community dynamics within decomposing CWD. Reduced moisture 
availability at forest edges can affect the growth and activity of saprotrophic fungi (Crockatt \& Bebber, 2015; Snäll \& Jonsson, 2001) and mycorrhizal fungi (Boeraeve et al., 2019). In addition, the abundance of white rot species, such as Xeromphalina campanella, Rigidoporus sp. and Skeletocutis odora, is positively correlated with moisture content (Fukasawa et al., 2015, 2018).

Here, we compare rates of decomposition and microbial communities in CWD in the interior and edges of a subtropical forest ecosystem. We measured two-year mass loss of CWD of Pinus taiwanensis Hayata and Cinnamomum camphora (Linn.) Presl at the forest edge and $60 \mathrm{~m}$ into the forest and characterized the microbial community in the decaying CWD. The experiment was conducted at sites at two elevations (215m and 1400m a.s.1.). Specifically, we asked: (1) do CWD mass loss rates differ between forest edge and forest interior positions? (2), do microbial communities in decaying CWD differ between forest edge and interior positions? and (3) how do characteristics of the microbial community relate to environmental conditions in the two environments? Based on studies from temperate forests, we hypothesize that CWD decomposition rates will be lower at the forest edge than in the forest interior and that the differences will be related to changes in microbial communities and moisture.

\section{Materials and methods}

\subsection{Study area}

This field research was conducted in a mixed coniferous-broad-leaved forest (CBF) at Lushan Mountain in Jiangxi Province, China $\left(29^{\circ} 31^{\prime} \sim 29^{\circ} 41^{\prime} \mathrm{N}, 115^{\circ} 51^{\prime} \sim 116^{\circ} 07^{\prime}\right.$ E). The area is characterized as a subtropical monsoon climate with four distinct seasons. Mean annual precipitation and temperature range from 1308 to $2068 \mathrm{~mm}$, and from 17.1 to $11.6^{\circ} \mathrm{C}$, respectively 
(Wu et al., 2019b). According to the FAO soil texture classification, soil types in Lushan change from ferric alisols at low elevations to haplic alisols at high ones (Liu \& Wang, 2010; Wu et al., 2018b). Mixed coniferous-broad-leaved forests are dominated by several Platycarya strobilacea and Acer davidii species, and some deciduous woodland species and shrubs (Liu \& Wang, 2010).

\subsection{Sampling design}

In December 2015, study sites were established in a mixed coniferous-broad-leaved forest at two altitudes (215m and $1400 \mathrm{~m})$. The sites at the two altitudes had similar aspect, slope steepness and position, stand age, and understory vegetation. Characteristics of the soils at the two sites are provided in Appendix 1. At each site, three plots were established within 0-5 m (Plot one: $2 \mathrm{~m}$, Plot two: $3 \mathrm{~m}$, Plots three: $2.5 \mathrm{~m}$ ) of the forest edge, and another three plots were established $60 \mathrm{~m}$ (Plot one: $60 \mathrm{~m}$, Plot two: $59.5 \mathrm{~m}$, Plots threee: $59 \mathrm{~m}$ ) inside the forest. The two tree species selected for CWD were Pinus taiwanensis Hayata and Cinnamomum camphora (Linn.) Presl. Fresh logs about $15 \mathrm{~cm}$ in central diameter were selected and cut into segments about $150 \mathrm{~cm}$ long (Table 1). Two CWD segments of each tree species were placed flush on the ground $30 \mathrm{~cm}$ from one another and $35 \mathrm{~cm}$ from the boundary of each plot. Therefore, a total of 48 CWD segments ( 2 altitudes $\times 2$ edge distances $\times 3$ plots $\times 2$ CWD species $\times 2$ segments) were tested.

\subsection{Wood physicochemical properties analysis}

A 2-cm-thick disk of each CWD was collected from a randomly selected place on each of the 48 logs at the beginning of the experiment and after 3, 6, 9, 12, 15, 18, 21, and 24 months. Disks were sealed in a plastic bag to preserve their moisture content before being transferred to the laboratory (Wu et al., 2018a, 2019a). The disk samples were collected more than $80 \mathrm{~cm}$ from the mid of wood. Each CWD sample was weighed and then oven-dried at $70^{\circ} \mathrm{C}$ and re-weighed, and 
their moisture content was calculated using equation (1).

$$
M_{C W D}=\frac{W_{w}-W_{d}}{W_{d}}
$$

where $\mathrm{M}_{\mathrm{CWD}}(\%)$ was the moisture content of each CWD during each measurement, $W_{\mathrm{w}}(\mathrm{g})$ was the wet wood weight, and $W_{\mathrm{d}}(\mathrm{g})$ was the dry weight.

The density of each CWD was calculated using equation (2): First, the weights of the disks of the CWD were measured $(\mathrm{m}, \mathrm{g})$, and the disks were placed in a container with a specific amount of water and wood disks in the container $\left(v_{1}, \mathrm{ml}\right)$, the initial volume of water $\left(v_{2}, \mathrm{ml}\right)$, and the density of each CWD sample $\left(\rho, \mathrm{g} / \mathrm{cm}^{3}\right)$ was calculated.

$$
\rho=m /\left(v_{1}-v_{2}\right)
$$

Mass loss from each CWD was calculated using equation (3).

$$
M L_{C W D}=\frac{M_{i}-M_{t}}{M_{i}}
$$

where $M L_{C W D}(\%)$ was the mass loss of each CWD sample during each measurement, $M_{i}(\mathrm{~g})$ was the initial dry mass, and $M_{t}(\mathrm{~g})$ was the wood mass after 3, 6, 9, 12, 15, 18, 21 or 24 months.

CWD temperature was measured at approximately $2 \mathrm{~cm}$ depth using a hand-held long-stem thermometer (Model SK-250WP, Sato Keiryoki Mfg. Co. Ltd, Tokyo, Japan). Concentrations of C and $\mathrm{N}$ in each CWD sample were determined using a TOC analyzer (Vario TOC, Elementar, German), and concentrations of lignin and cellulose were determined using the ADF-sulphuric method (Rowland et al., 1994) and the Kjeldahl method (K-370, Buchi Scientific Instruments, Switzerland). Soil available N (sum of the ammonium nitrogen, nitrate nitrogen, amino acid and readily hydrolyzed proteins nitrogen) was measured through the oxidation hydrolyzed into ammonia nitrogen, then absorbed by the boric acid solution and determined by sulfuric acid and titration (Liu, 1996). Soil available $\mathrm{P}$ was extracted using $\mathrm{HCl}-\mathrm{NH}_{4} \mathrm{~F}$ solution and determined by MolybdenumAntimony Anti colorimetric assay (Liu, 1996). Relative to P. taiwanensis, C. camphora CWD had 
higher initial concentrations of carbon and lignin, and lower cellulose (Appendix 1). Soil organic matter, $\mathrm{N}$, hydrolyzed $\mathrm{N}$ and available $\mathrm{P}$ significantly differed between the two sites (Appendix 2).

\subsection{Phospholipid fatty acid (PLFA) analyses}

Microbial biomass and the relative index of bacterial to fungal biomass were estimated by PLFA analysis (Bossio \& Scow, 1998; Olsson et al., 1999). CWD samples and mineral soil (0-5 cm) under each CWD segment were collected every three months during the study period and stored at $-20^{\circ} \mathrm{C}$ for PLFA analysis. Concentrations of each PLFA were calculated relative to the 19:0 internal standard concentration. Total microbial biomass summed by each individual PLFAs (ng g ${ }^{-1}$ dry wood material). Microbial groups of bacteria (B), fungi (F), Gram-negative bacteria (G-), Grampositive bacteria $\left(\mathrm{G}^{+}\right)$, actinomycetes (ACT), and arbuscular mycorrhizal fungi (AMF) were biomarkers by the characteristic fatty acids (Appendix 3) (Olsson et al., 1999).

\subsection{Data analysis}

The effects of month, distance from the edge, and their interactions on temperature, moisture content, and mass loss of CWD were determined by repeated measures ANOVA for each species.

We used three-way ANOVA to test the distance from edge, tree species, and altitude gradient on mass loss and microbial community changes. Due to significant interactions among altitude, edge distance, and species, all comparisons among altitude, edge distance or tree species were performed using one-way ANOVA of Dunnett's post-hoc. The microbial communities in the soil $(0-5 \mathrm{~cm})$, under each CWD and in the CWD itself were compared by simple correlation analysis, and differences in the PLFA signatures of the microbial community under CWD or soil among different treatments (tree species, altitude gradient or edge distance) were tested by redundancy analysis (RDA). All data were analysed using SPSS 20.0 (SPSS Inc., Chicago, USA). Differences were 
considered significant at $p<0.05$.

\section{Results}

\subsection{Distance from edge effects}

During the two-year experimental period, the mean mass loss of $P$. taiwanensis and $C$. camphora $60 \mathrm{~m}$ away from the forest edge was significantly greater than that at the forest edge at both sites (Table 2 and Fig. 1). The moisture content of the CWD segments was also greater $60 \mathrm{~m}$ from the forest edge than at the edge throughout the two-year period (Fig. 2). There was a significant positive correlation between CWD's mass loss and moisture content for each altitude, edge distance, and tree species (Table 3).

\subsection{Microbial community composition}

Concentrations of total PLFA, total fungi, total bacteria, $\mathrm{G}^{+}$bacteria, $\mathrm{G}^{-}$bacteria, soil fungi, and AMF in the soil beneath CWD of both tree species were all higher $60 \mathrm{~m}$ from the forest edge than at the forest edge (Fig. 3). Concentrations of total PLFA, total bacteria, total fungi, $\mathrm{G}^{+}$bacteria, $\mathrm{G}^{-}$bacteria, fungi, and AMF in the CWD of both tree species were also higher $60 \mathrm{~m}$ from the forest edge than at the edge (Fig. 4). The concentrations of fungal components (total fungi, fungi, and AMF) in the CWD were generally higher than that of bacteria components (total bacteria, $\mathrm{G}^{+}$ bacteria, and $\mathrm{G}^{-}$bacteria) (Fig. 4).

\subsection{Relationship between soil and CWD microbial communities}

Correlations between microbial communities in CWD and soil (Table 4) were generally positive in plots $60 \mathrm{~m}$ from the forest edge. There were some negative correlations between CWD fungi and soil fungi at the forest edge (Table 4). 
3.4. Effects of edge distance and tree species on CWD microbial community

Distance to the forest edge had a larger influence on the CWD microbial community than did tree species or altitude (Table 5). Distance to edge explained $17.4 \%$ of the total variation, while tree species and altitude explained $3.1 \%$ and $10.9 \%$, respectively (Table 5).

\section{Discussion}

Consistent with our hypothesis, mass loss of CWD within this studied subtropical forest was > $15 \%$ greater than that at the edge, at both altitudes, which is lower to the $23 \%$ greater mass loss of woodblocks placed $100 \mathrm{~m}$ into the forest than at the edge in a temperate forest (Crockatt \& Bebber, 2015). The CWD at the forest edge had lower moisture content throughout the study, which is consistent with our hypothesis. Similarly, Crockatt and Bebber (2015) reported that the moisture content of the woodblocks increased with distance from the edge.

The higher moisture content of soil and wood in the forest interior probably facilitated the detection and colonization of CWD by microbes, which are largely soil-dwelling (Mäkipää et al., 2017; Fukasawa et al., 2018; Law et al., 2019). Malmivaara-Lämsä et al. (2008) found that fungal biomass was about $30 \%$ higher $20 \mathrm{~m}$ inside the forest when compared to the edge, due to the higher humus moisture content inside the forest. In our study, CWD of both tree species in the forest interior had greater total PLFA, total bacteria, total fungi, $\mathrm{G}^{+}$bacteria, $\mathrm{G}^{-}$bacteria, fungi, and AMF compared to CWD at the forest edge. Other studies have reported increased activity of both wood- and litterdecomposing saprotrophic fungi with distance from the forest edge (Snäll \& Jonsson, 2001; Riutta et al., 2012; Crockatt \& Bebber, 2015; Fukasawa et al., 2015, 2018; Ruwanza, 2019). Previous studies also reported that the abundance of mycorrhizal fungi was greater within forests than at 
edges (Malmivaara-Lämsä et al., 2008; Kjøller et al., 2012; Erlandson et al., 2016; Boeraeve et al., 2019). The abundance and diversity of various soil fauna groups may also be reduced near forest edges (Goosem, 2000; Laurance et al., 2002; Lehtinen et al., 2003; Watson et al., 2004; Laurance, 2004; Pfeifer et al., 2017).

This study investigated CWD decomposition during a two-year experimental period, a relatively short time span considering the turnover time of wood. Long-term research is needed to organic-matter pools over a longer study period. Our sampling method-collecting a 2-cm-thick disk from the end part of each CWD segment-would have increased exposure of the segment to fungal invasion. This would overestimate actual rates of decomposition but should be more realistic than the common practice of using woodblocks or tongue depressors.

\section{Conclusion} moisture content. Distance from edge (17.4\%) was more important than tree species $(3.1 \%)$ and at forest edges need to be incorporated into global C models. 


\section{Acknowledgment}

We are grateful to the Lushan Mountain National Forest Ecological Station for providing the study sites. This study was financially supported by the National Natural Science Foundation of China (31960303, 31901292 and 31460185).

\section{Author Contributions}

All authors contributed to the study at various phases. Specifically, C.S.W., C.J.S., B.Y.L., Z.J.Z., H.K.W., Y.Z., and Y.Q.L. were responsible for study design, data collection and analysis, and writing the early drafts of this research. C.S.W., C.P., Y.Q.L. and G.G.W substantially contributed to interpreting and revising the manuscript.

\section{Conflicts of Interest}

The authors declare no conflict of interest.

\section{References:}

Albiero-Júnior, A., Venegas-González, A., Rodríguez-Catón, M., Oliveira, J. M., Longhi-Santos, T., Galvão, F., Temponi, L.G., Botosso, P.C., 2020. Edge Effects Modify the Growth Dynamics and Climate Sensitivity of Araucaria angustifolia Trees. Tree-Ring Research 76, 11-26.

Barlow, J., Lennox, G.D., Ferreira, J., Berenguer, E., Lees A.C., Nally R.M., Thomson, J.R., Ferraz, S.B., Louzada, J., Oliveira, V.H.F., Parry, L., Solar, R.R.C., Vieira, I.C.G., Aragão, L., Begotti, R.A., Braga, R.F., Cardoso, T.M., de Oliveira, R.C., Souza, C.M., Moura, N.G., Nunes, S.S., Siqueira, J.V., Pardini, R., Silveira, J.M., Vaz-de-Mello, F.Z., Veiga, R.C.S.V., Venturieri, A., Gardner, T.A., 2016. Anthropogenic disturbance in tropical forests can double biodiversity loss from deforestation. Nature 53, 144-147. 
Boddy, L., 2001. Fungal community ecology and wood decomposition processes in angiosperms: from standing tree to complete decay of coarse woody debris. Ecological Bulletins 2001, 43-56.

Boddy, L., Owens, E.M., Chapela, I.H., 1989. Small scale variation in decay rate within logs one year after felling: effect of fungal community structure and moisture content. FEMS Microbiology Letters 62, 173-184.

Boeraeve, M., Honnay, O., Jacquemyn, H., 2019. Forest edge effects on the mycorrhizal communities of the dual-mycorrhizal tree species Alnus glutinosa (L.) Gaertn. Science of the Total Environment $666,703-712$.

Bossio, D.A., Scow, K.M., 1998. Impacts of carbon and flooding on soil microbial communities: phospholipid fatty acid profiles and substrate utilization patterns. Microbial Ecology 35, 265-278.

Castaño, C., Lindahl, B.D., Alday, J.G., Hagenbo, A., de Aragón, J., Parladé, J., Pera, J., Bonet, J.A., 2018. Soil microclimate changes affect soil fungal communities in a Mediterranean pine forest. New Phytologist 220, 1211-1221.

Crockatt, M.E., Bebber, D.P., 2015. Edge effects on moisture reduce wood decomposition rate in a temperate forest. Global Change Biology 21, 698-707.

Didham, R.K., Ewers, R.M., 2012. Predicting the impacts of edge effects in fragmented habitats: Laurance and Yensen's core area model revisited. Biological Conservation 155, 104-110.

Erlandson, S.R., Savage, J.A., Cavender-Bares, J.M., Peay, K.G., 2016. Soil moisture and chemistry influence diversity of ectomycorrhizal fungal communities associating with willow along an hydrologic gradient. FEMS Microbiology Ecology 92, fiv148.

FAO., 2010. Global Forest Resources Assessment 2010. Food and Agriculture Organization of the United Nations, Rome. 
Forrester, J.A., Mladenoff, D.J., Gower, S.T., Stoffel, J.L., 2012. Interactions of temperature and moisture with respiration from coarse woody debris in experimental forest canopy gaps. Forest Ecology and Management, 265, 124-132.

Frostegård, Å., Bååth, E., 1996. The use of phospholipid fatty acid analysis to estimate bacterial and fungal biomass in soil. Biology and Fertility of Soils 22, 59-65.

Frostegård, A., Tunlid, A., Bååth, E., 2011. Use and misuse of PLFA measurements in soils. Soil Biology and Biochemistry, 43, 1621-1625.

Fukasawa, Y., Hyodo, F., Kawakami, S.I., 2018. Foraging association between myxomycetes and fungal communities on coarse woody debris. Soil Biology and Biochemistry 121, 95-102.

Fukasawa, Y., Matsuoka, S., 2015. Communities of wood-inhabiting fungi in dead pine logs along a geographical gradient in Japan. Fungal Ecology 18, 75-82.

Goosem, M., 2000. Effects of tropical rainforest roads on small mammals: edge changes in community composition. Wildlife Research 27, 151-163.

Haddad, N.M., Brudvig, L.A., Clobert, J., Davies, K.F., Gonzalez, A., Holt, R.D., Lovejoy, T.E., Sexton, J.O., Austin, M.P., Collins, C.D., Cook, W.M., Damschen, E.I., Ewers, R.M., Foster, B.L., Jenkins, C.N., King, A.J., Laurance, W.F., Levey, D.J., Margules, C.R., Melbourne, B.A., Nichoils, A.O., Orrock, J.L., Song, D.X., Townshend, J.R., 2015. Habitat fragmentation and its lasting impact on Earth's ecosystems. Science Advances 1, e1500052.

Intergovernmental Panel on Climate Change., 2014: Climate Change 2014: Synthesis Report, in: Contribution of Working Groups I, II and III to the Fifth Assessment Report of the Intergovernmental Panel on Climate Change, IPCC Geneva, Switzerland, 151 pp.

Kjøller, R., Nilsson, L.O., Hansen, K., Schmidt, I.K., Vesterdal, L., Gundersen, P., 2012. Dramatic 

along a stand-scale nitrogen deposition gradient. New phytologist 194, 278-286.

Laurance, W.F., 2004. Forest-climate interactions in fragmented tropical landscapes. Philosophical Transactions of the Royal Society of London Series B: Biological Sciences, 359, 345-352.

Laurance, W.F., Lovejoy, T.E., Vasconselos, H.L., Bruna, E.M., Didham, R.K., Stouffer, P.C., Gascon,

Malmivaara-Lämsä, M., Hamberg, L., Haapamäki, E., Liski, J., Kotze, D.J., Lehvävirta, S., Fritze, H., 

collapse and carbon emissions from forest fragmentation in the Brazilian Amazon. Journal of Geophysical Research: Biogeosciences 115, G03027.

Olsson, P.A., Jakobsen, I., Thingstrup, I., Bååth, E., 1999. Estimation of the biomass of arbuscular mycorrhizal fungi in a linseed field. Soil Biology and Biochemistry 31, 1879-1887.

Pan, Y.D., Birdsey, R.A., Fang, J.Y., Houghton, R., Kauppi, P.E., Kurz, W.A., Phillips, O.L., Shvidenko, A., Lewis, S.L., Canadell, J.G., Ciais, P., Jackson, R.B., Pacala, S.W., McGuire, A.D., Piao, S.L., Rautiainen, A., Sitch, S., Hayes, D., 2011. A large and persistent carbon sink in the world's forests. Science 333, 988-993.

Pfeifer, M., Lefebvre, V., Peres, C.A., Banks-Leite, C., Wearn, O.R., Marsh, C.J., Butchart, S.H.M., Arroyo-Rodriguez, V., Barlow, J., Cerezo, A., Cisneros, L., D'Cruze, N., Faria, D., Hadley, A., Harris, S.M., Klingbeil, B.T., Kormann, U., Lens, L., Medina-Rangel, G.F., Morante-Filho, J.C., Olivier, P., Peter, S.L., Pidgeon, A., Ribeiro, D.B., Scherber, C., Schneider-Maunoury, L., Struebig, M., UrbinaCardona, N., Watling, J.I., Willig, M.R., Wood, E.M., Ewers, R.M., 2017. Creation of forest edges has a global impact on forest vertebrates. Nature 551, 187-191.

Purahong, W., Kahl, T., Krüger, D., Buscot, F., Hoppe, B., 2019. Home-Field Advantage in Wood Decomposition Is Mainly Mediated by Fungal Community Shifts at "Home” Versus “Away". Microbial Ecology 78, 725-736.

Riutta, T., Slade, E.M., Bebber, D.P., Taylor, M., Malhi, Y., Riordan, P., Macdonald, D.W., Morecroft, M.D., 2012. Experimental evidence for the interacting effects of forest edge, moisture and soil macrofauna on leaf litter decomposition. Soil Biology and Biochemistry, 49, 124-131. 
Rowland, A.P., Roberts, J.D., 1994. Lignin and cellulose fractionation in decomposition studies using acid-detergent fibre methods. Communications in Soil Science and Plant Analysis 25, 269-277.

Ruwanza, S., 2019. The Edge Effect on Plant Diversity and Soil Properties in Abandoned Fields Targeted for Ecological Restoration. Sustainability 11, 140.

Snäll, T., Jonsson, B.G., 2001. Edge effects on six polyporous fungi used as old-growth indicators in Swedish boreal forest. Ecology Bulletins 255-262.

Tang, X.L., Zhao, X., Bai, Y.F., Tang, Z.Y., Wang, W.T., Zhao, Y.C., Wan, H.W., Xie, Z.Q., Shi, X.Z., Wu, B.F., Wang, G.X., Yan, J.H., Ma, K.P., Du, S., Li, S.G., Han, S.J., Ma, Y.X., Hu, H.F., He, N.P., Yang, Y.H., Han, W.X., He, H.L., Yu, G.R., Fang, J.Y., Zhou, G.Y., 2018. Carbon pools in China's terrestrial ecosystems: New estimates based on an intensive field survey. Proceedings of the National Academy of Sciences of the United States of America 115, 4021-4026.

van der Linde, S., Suz, L.M., Orme, C.D.L., Cox, F., Andreae, H., Asi, E., Atkinson, B., Benham, S., Carroll, C., Cools, N., De Vos, B., Dietrich, H.-P., Eichhorn, J., Gehrmann, J., Grebenc, T., Gweon, H.S., Hansen, K., Jacob, F., Kristöfel, F., Lech, P., Manninger, M., Martin, J., Meesenburg, H., Merilä, P., Nicolas, M., Pavlenda, P., Rautio, P., Schaub, M., Schröck, H.-W., Seidling, W., Šrámek, V., Thimonier, A., Thomsen, I.M., Titeux, H., Vanguelova, E., Verstraeten, A., Vesterdal, L., Waldner, P., Wijk, S., Zhang, Y., Žlindra, D., Bidartondo, M.I., 2018. Environment and host as large-scale controls of ectomycorrhizal fungi. Nature 558, 243-248.

Watson, J.E.M., Whitacker, R.J., Dawson, T.P., 2004. Habitat structure and proximity to forest edge affect the abundance and distribution of forest-dependent birds in tropical coastal forests of southeastern Madagascar. Biological Conservation 120, 311-327.

Wu, C.S., Ulyshen, M., Shu, C.J., Zhang, Z.J., Zhang, Y., Liu, Y.Q., Wang, G.G., 2021. Stronger effects 

Management 493, 119263.

Wu, C.S., Mo, Q.F., Wang, H.K., Zhang, Z.J., Huang, G.X., Ye, Q., Zou, Q., Kong, F.Q., Liu, Y.Q., Wang, G.G., 2018b. Moso bamboo (Phyllostachys edulis (Carriere) J. Houzeau) invasion affects soil phosphorus dynamics in adjacent coniferous forests in subtropical China. Annals of Forest Science $75,24$.

Wu, C.S., Wang, H.K., Mo, Q.F., Zhang, Z.J., Huang, G.X., Kong, F.Q., Liu, Y.Q., Wang, G.G., $2019 a$. Effects of elevated UV-B radiation and $\mathrm{N}$ deposition on the decomposition of coarse woody debris. Science of the Total Environment 663, 170-176.

Wu, C.S., Zhang, Z.J., Shu, C.J., Mo, Q.F., Wang, H.K., Kong, F.Q., Wang, G.G., Liu, Y.Q., 2020. The Ecological Applications 6, 257-262. 
380

381

382

383

384

385

386

387

388

389

390

391

392

393

394

395

396

397

398

399

400 


\section{Tables and Figures}

402 Table 1. Initial diameter, length and density (mean $\pm \mathrm{SE}, \mathrm{n}=6$ ) of the log segments of the two tree species at each

403 altitude ( $215 \mathrm{~m}$ and $1400 \mathrm{~m})$ and forest edge distance (edge and $60 \mathrm{~m}$ from the forest edge). Note: experiment material

404 was all of similar decay stage.

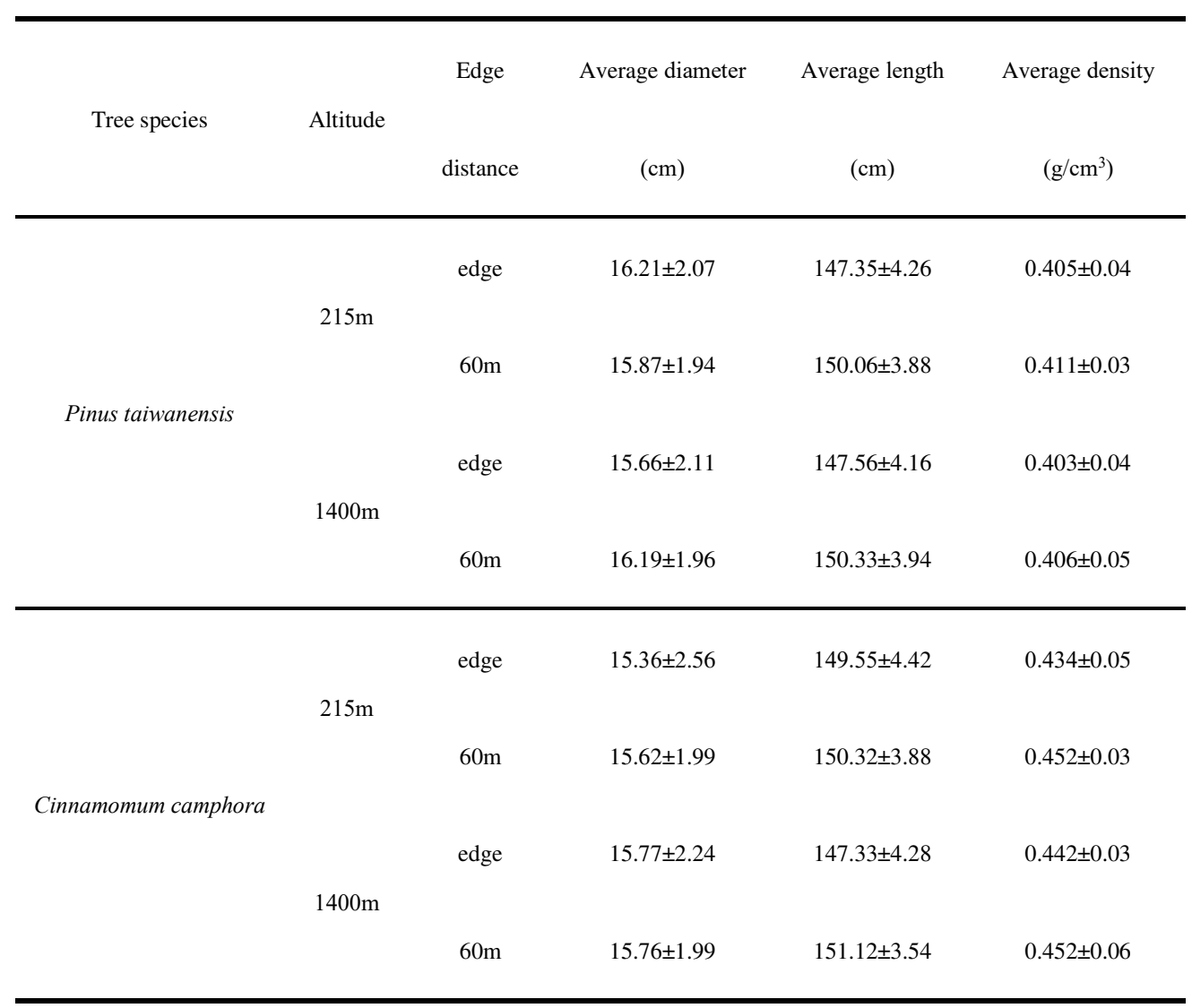

405

406

407

408

409

410 
413 Table 2. Two-year average mass loss, temperature and moisture content of CWD (mean \pm SE, $\mathrm{n}=6$ ) of the two studied

414 species at the two altitudes $(215 \mathrm{~m}$ and $1400 \mathrm{~m})$ and forest edge distances (edge and $60 \mathrm{~m}$ from the forest edge) in

415 Lushan Mountain, China. Different uppercase letters indicate significant differences between edge distances for the

416 same species (e.g., Pinus taiwanensis or Cinnamomum camphora) at $p<0.05$ ) and altitude. Different lowercase

417 letters indicate significant differences among the two species for the same edge distance and altitude $(p<0.05)$.

418 Different lowercase letters in brackets indicate significant differences between altitudes for the same edge distance

419 and tree species $(p<0.05)$.

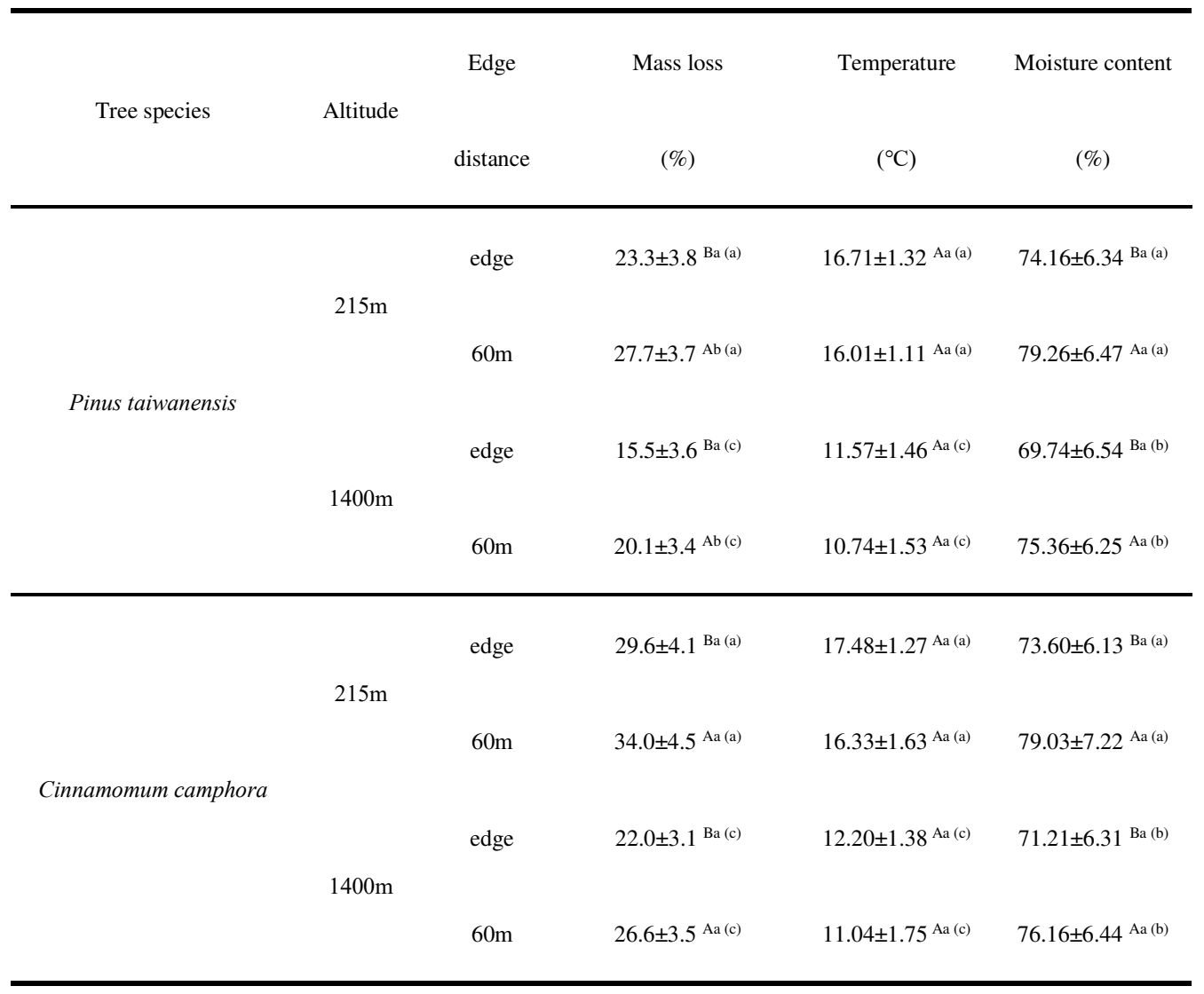


424 Table 3. Correlations of mass loss with moisture content and temperature of CWD by altitude, forest edge distance,

425 and tree species. $n s$ not significant, $* p<0.05, * * p<0.01, * * * p<0.001$.

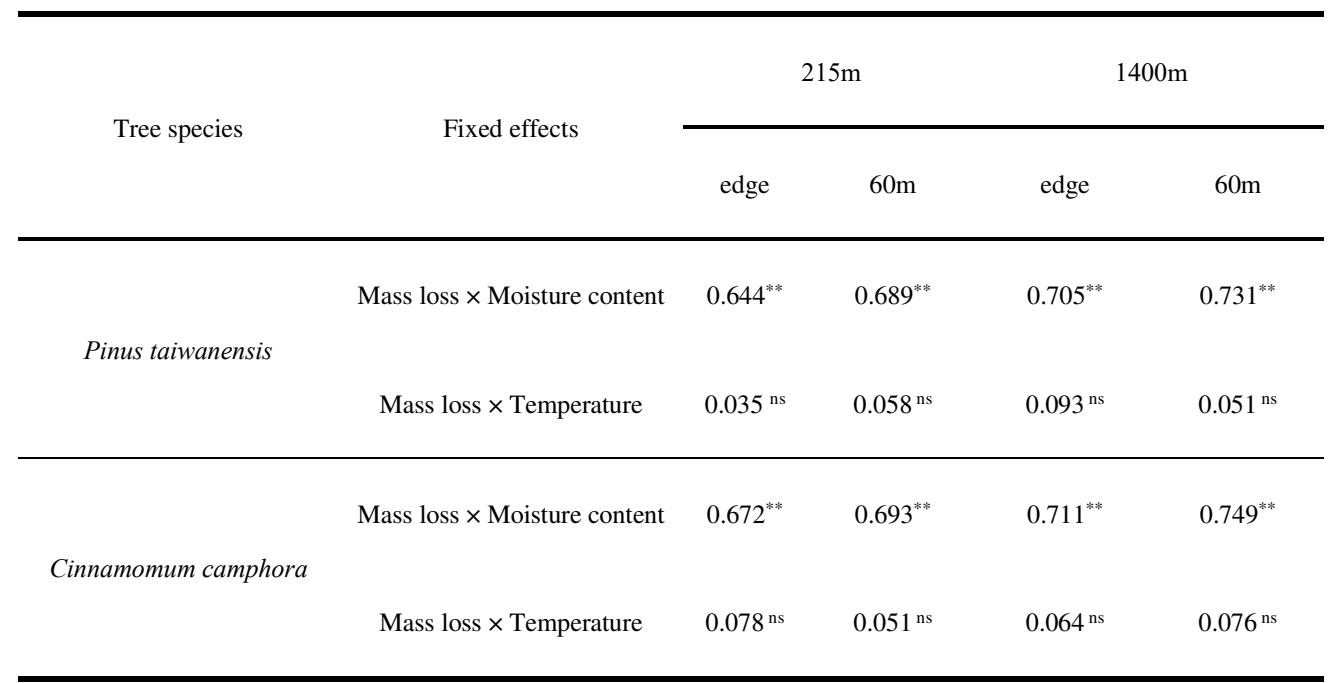

426 
440 Table 4. Correlation between the composition of different phospholipid fatty acid (PLFA) (ng g ${ }^{-1}$ dry mass)

441 signatures of CWD and soil for each altitude, forest-edge distance, and tree-species combination. Total, total PLFA

442 concentrations; B, bacterial PLFAs; F, fungal PLFAs; F/B, the fungal to bacterial ratio; $\mathrm{G}^{+}$, Gram-positive bacteria;

$443 \mathrm{G}^{-}$, Gram-negative bacteria; $\mathrm{G}^{+} / \mathrm{G}^{-}$, ratio of Gram-positive to Gram-negative bacteria; AMF, arbuscular mycorrhizal

444 fungi. $n s$ not significant, $* p<0.05, * * p<0.01, * * * p<0.001$.

\begin{tabular}{|c|c|c|c|c|c|c|c|c|c|}
\hline Fixed effects & Altitude & Edge distance & $\mathrm{AMF}$ & Fungi & Total Fungi & $\mathrm{G}^{+}$ & $\mathrm{G}^{-}$ & Total B & Total \\
\hline \multirow{6}{*}{ Pinus taiwanensis $\times$} & \multirow{3}{*}{$215 \mathrm{~m}$} & edge & $0.643^{*}$ & $-0.611^{*}$ & $-0.678^{*}$ & $0.822^{*}$ & $0.662^{*}$ & $0.704^{* *}$ & $0.771^{* *}$ \\
\hline & & & & & & & & & \\
\hline & & $60 \mathrm{~m}$ & $0.801^{* *}$ & $0.778^{* *}$ & $0.791^{* *}$ & $0.767^{* *}$ & $0.683^{*}$ & $0.778^{* *}$ & $0.804^{* *}$ \\
\hline & \multirow{3}{*}{$1400 \mathrm{~m}$} & edge & $0.654^{*}$ & $-0.647^{*}$ & $-0.674^{*}$ & $0.789^{* *}$ & $0.771^{*}$ & $0.782^{* *}$ & $0.801^{* *}$ \\
\hline & & & & & & & & & \\
\hline & & $60 \mathrm{~m}$ & $0.812^{* *}$ & $0.785^{* *}$ & $0.799^{* *}$ & $0.801^{* *}$ & $0.788^{*}$ & $0.784^{* *}$ & $0.797^{* *}$ \\
\hline & & edge & $0.634^{*}$ & $-0.645^{*}$ & $-0.635^{*}$ & $0.811^{* *}$ & $0.642^{*}$ & $0.661^{*}$ & $0.788^{* *}$ \\
\hline & $215 \mathrm{~m}$ & & & & & & & & \\
\hline Cinnaтотит & & $60 \mathrm{~m}$ & $0.803^{* *}$ & $0.777^{* *}$ & $0.781^{* *}$ & $0.781^{* *}$ & $0.650^{*}$ & $0.789^{* * *}$ & $0.804^{* *}$ \\
\hline \multirow[t]{3}{*}{ camphora $\times$ Soil } & & edge & $0.639^{*}$ & $-0.627^{*}$ & $-0.647^{*}$ & $0.789^{* *}$ & $0.629^{*}$ & $0.796^{* *}$ & $0.792^{* *}$ \\
\hline & $1400 \mathrm{~m}$ & & & & & & & & \\
\hline & & $60 \mathrm{~m}$ & $0.811^{* *}$ & $0.784^{* *}$ & $0.796^{* *}$ & $0.801^{* *}$ & $0.640^{*}$ & $0.769^{* * *}$ & $0.781^{* *}$ \\
\hline
\end{tabular}

445

446

447

448

449

450

451 
453 Table 5. Effects of tree species, altitude, and forest-edge distance on the selected phospholipid fatty acid (PLFAs)

454 signatures of CWD tested with redundancy analysis (RDA).

\begin{tabular}{ccccc}
\hline Explanatory variable & Explained variance \% & Contribution \% & Pseudo-F & $P(<0.05)$ \\
\hline Tree species & 3.1 & 9.5 & 3.8 & 0.036 \\
Altitude & $\mathbf{1 0 . 9}$ & 37.2 & 18.8 & 0.002 \\
Forest edge distance & $\mathbf{1 7 . 4}$ & & & \\
\hline
\end{tabular}

455

456

457

458

459

460

461

462

463

464

465

466

467

468

469 
471 Appendix 1. Initial chemical characteristics of CWD (fresh wood) of the two tree species at each altitude (215m and $1400 \mathrm{~m}$ ) and forest-edge distance (edge and 60m from the forest edge) in Lushan Mountain of subtropical China.

473 Different lowercase letters indicate significant differences between tree species for the same forest edge distance and

474 altitude $(p<0.05)$. Note: The concentrations of $\mathrm{C}, \mathrm{N}$, lignin, and cellulose in CWD of the same species did not

475 significantly differ $(p<0.05)$ between the two forest-edge distances (i.e., edge $v s .60 \mathrm{~m})$.

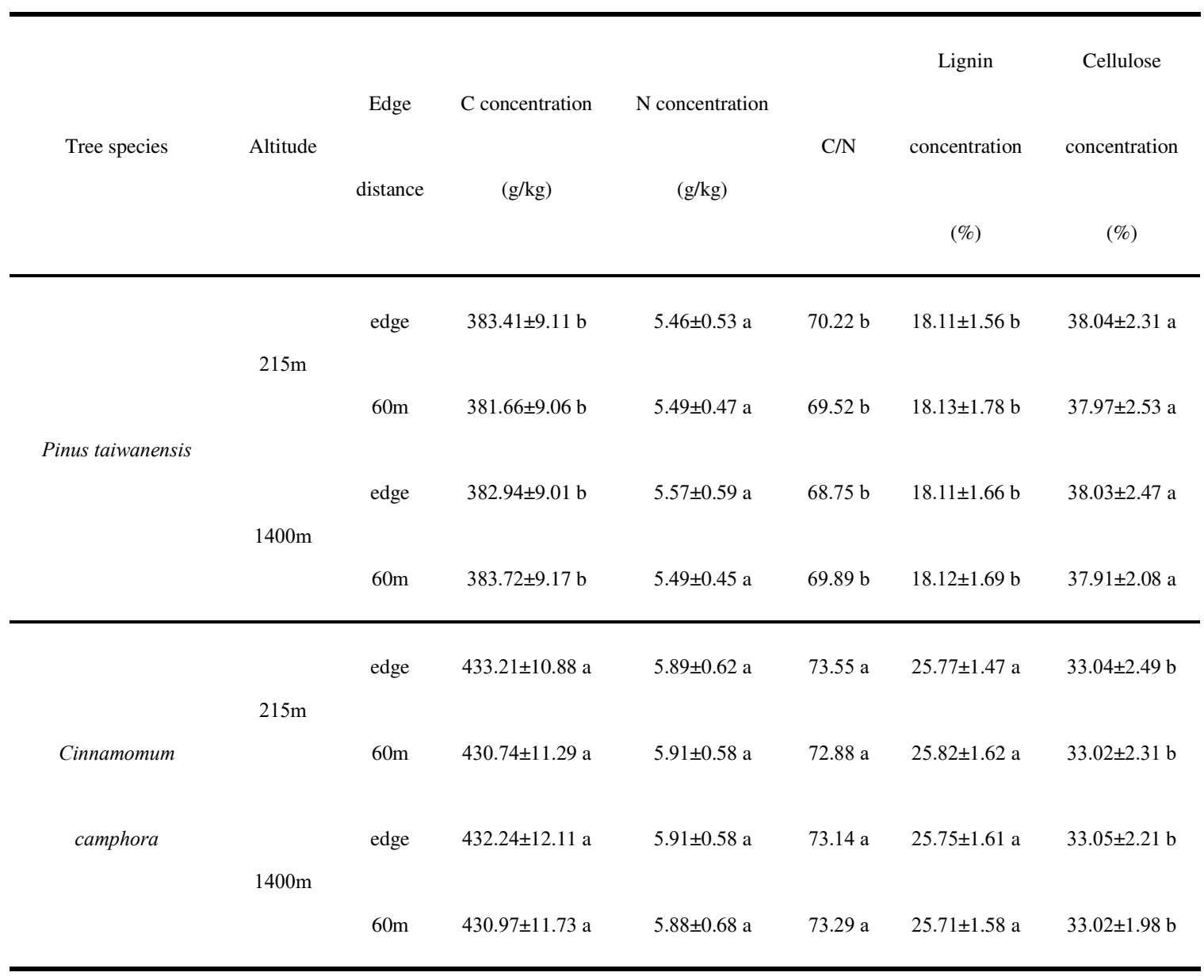

476 
482 Appendix 2. Initial physicochemical properties ( $\pm \mathrm{SE}, \mathrm{n}=24)$ of the upper $15 \mathrm{~cm}$ of the soil at the two sites. Different

483 lowercase letters indicate significant differences among the altitudes for the same index $(p<0.05)$.

\begin{tabular}{|c|c|c|c|c|c|c|c|c|c|}
\hline \multirow[b]{2}{*}{ Altitude } & Organic matter & $\mathrm{N}$ & Hydrolyzed N & $\mathrm{P}$ & Available P & Available K & \multicolumn{3}{|c|}{ Bulk density } \\
\hline & $(\mathrm{g} / \mathrm{kg})$ & $(\mathrm{g} / \mathrm{kg})$ & $(\mathrm{mg} / \mathrm{kg})$ & $(\mathrm{g} / \mathrm{kg})$ & $(\mathrm{mg} / \mathrm{kg})$ & $(\mathrm{mg} / \mathrm{kg})$ & $\mathrm{pH}$ & $\left(\mathrm{g} / \mathrm{cm}^{3}\right)$ & Soil type \\
\hline $215 \mathrm{~m}$ & $38.62 \pm 3.91 \mathrm{c}$ & $1.74 \pm 0.12 \mathrm{~b}$ & $192.94 \pm 18.88 \mathrm{c}$ & $0.26 \pm 0.05 \mathrm{a}$ & $3.66 \pm 0.29 \mathrm{~b}$ & $41.78 \pm 3.21 \mathrm{~b}$ & $4.7 \pm 0.5 \mathrm{a}$ & $0.98 \pm 0.14 \mathrm{a}$ & Ferric alisols \\
\hline $1400 \mathrm{~m}$ & $51.36 \pm 4.56 \mathrm{a}$ & $2.01 \pm 0.22 \mathrm{a}$ & $215.17 \pm 21.02 \mathrm{a}$ & $0.29 \pm 0.05 \mathrm{a}$ & $4.09 \pm 0.32 \mathrm{a}$ & $47.35 \pm 4.86 \mathrm{a}$ & $4.8 \pm 0.4 \mathrm{a}$ & $0.93 \pm 0.13 \mathrm{a}$ & Haplic alisols \\
\hline
\end{tabular}

484

485

486

487

488

489

490

491

492

493

494

495

496

497

498 
500 Appendix 3. Biomarkers of selected phospholipid fatty acids (PLFAs) used in this study.

Groups $\quad$ Biomarker PLFAs

Bacteria

$\mathrm{G}^{+}$bacteria

$\mathrm{G}^{-}$bacteria

Fungi

Actinomycetes

AMF

Total biomass

502

503

504

505

506

507

508

509

510

511

512

513 

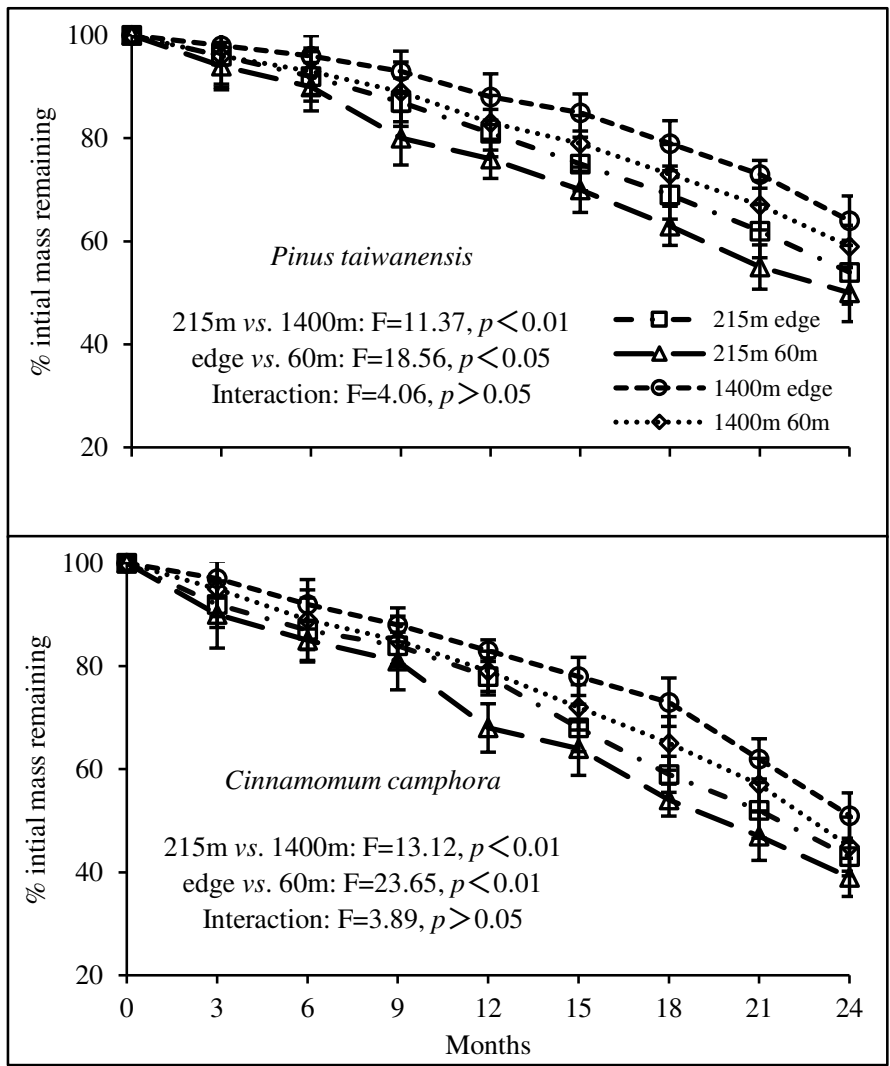
forest-edge distance (edge and $60 \mathrm{~m}$ from the forest edge) during the 24 -month incubation.

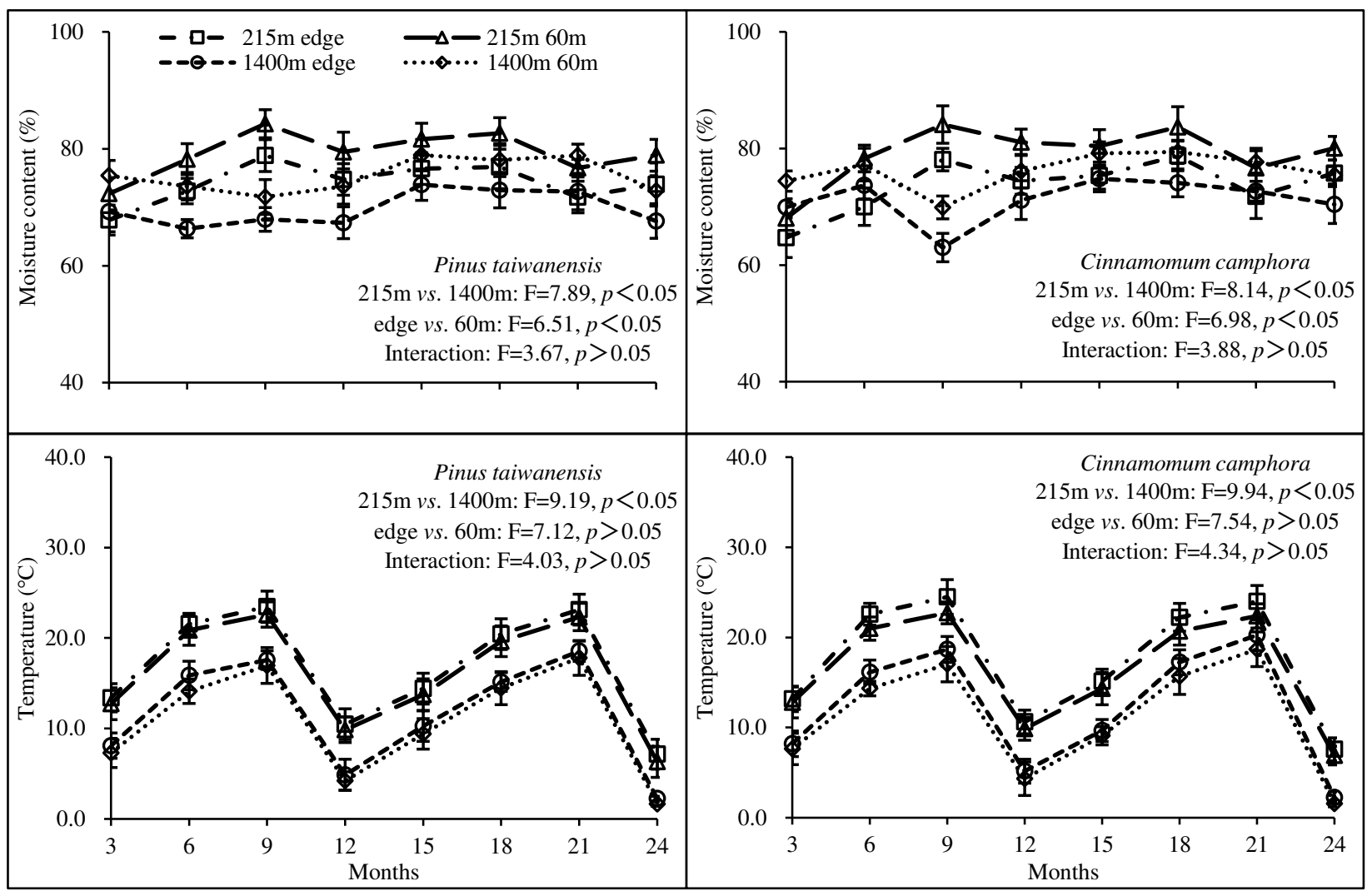


Figure 3. Soil phospholipid fatty acid (PLFA) (mean $\pm \mathrm{SE}$; $\mathrm{ng} \mathrm{g}^{-1}$ dry soil) signatures $(0-5 \mathrm{~cm})$ under CWD of the

two tree species at each forest-edge distance (edge and $60 \mathrm{~m}$ from the forest edge) and altitude $(215 \mathrm{~m}$ and $1400 \mathrm{~m})$ in

Gram-negative bacteria; AMF, arbuscular mycorrhizal fungi.

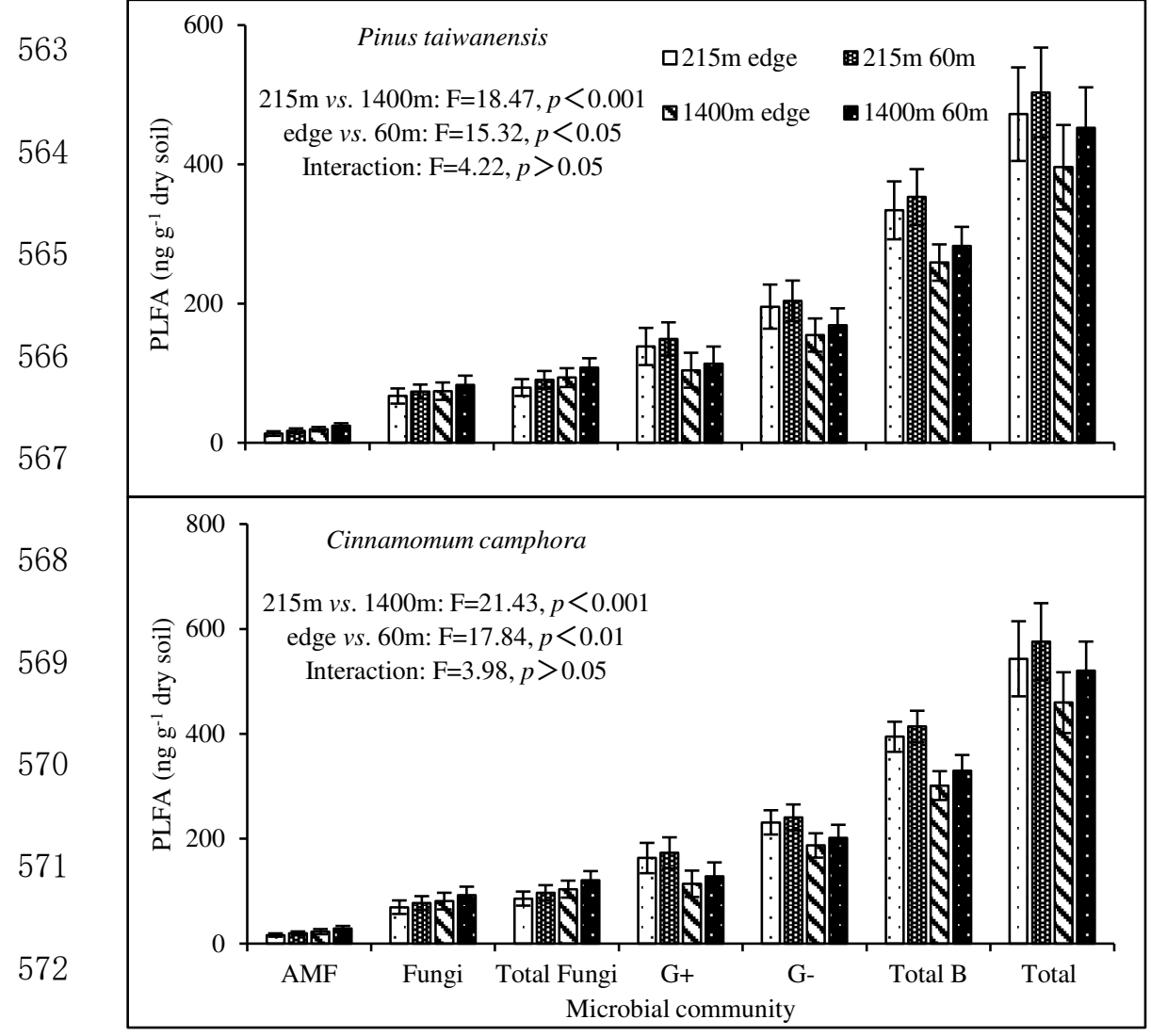

573 
Figure 4. Phospholipid fatty acid (PLFA) (mean $\pm \mathrm{SE}$; $\mathrm{ng} \mathrm{g}^{-1}$ dry wood material) signatures of the CWD of the two tree species at each forest-edge distance (edge and $60 \mathrm{~m}$ from the forest edge) and altitude $(215 \mathrm{~m}$ and $1400 \mathrm{~m})$ in Lushan Mountain of subtropical China. Total, total PLFA concentrations; B, bacterial PLFAs; F, fungal PLFAs; F/B, to Gram-negative bacteria; AMF, arbuscular mycorrhizal fungi.

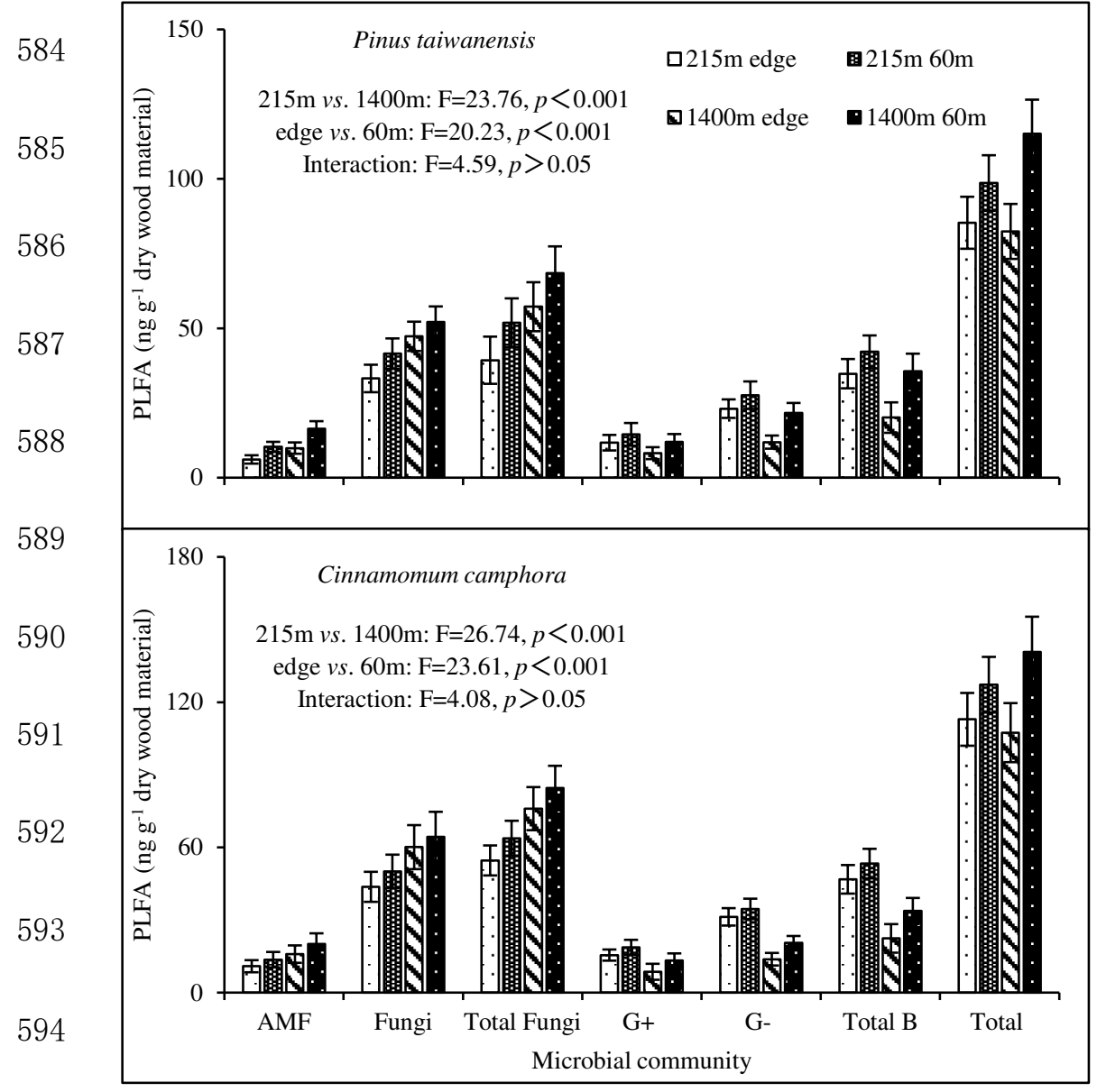


Figures

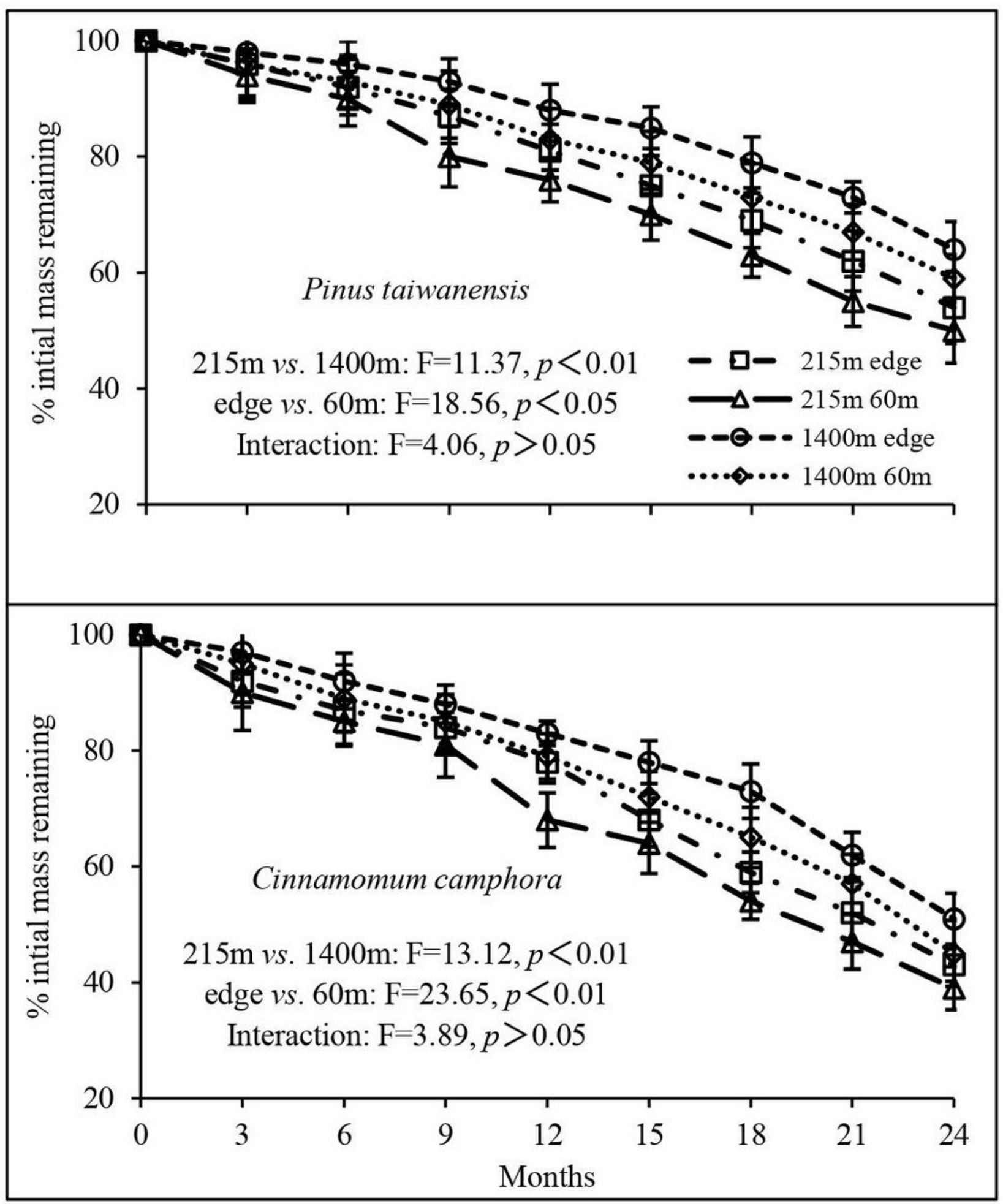

Figure 1

Patterns of mass loss of two tree species of CWD (fresh wood) at each altitude (215m and $1400 \mathrm{~m}$ ) and forest-edge distance (edge and $60 \mathrm{~m}$ from the forest edge) during 24 months of decomposition in Lushan Mountain of subtropical China. 


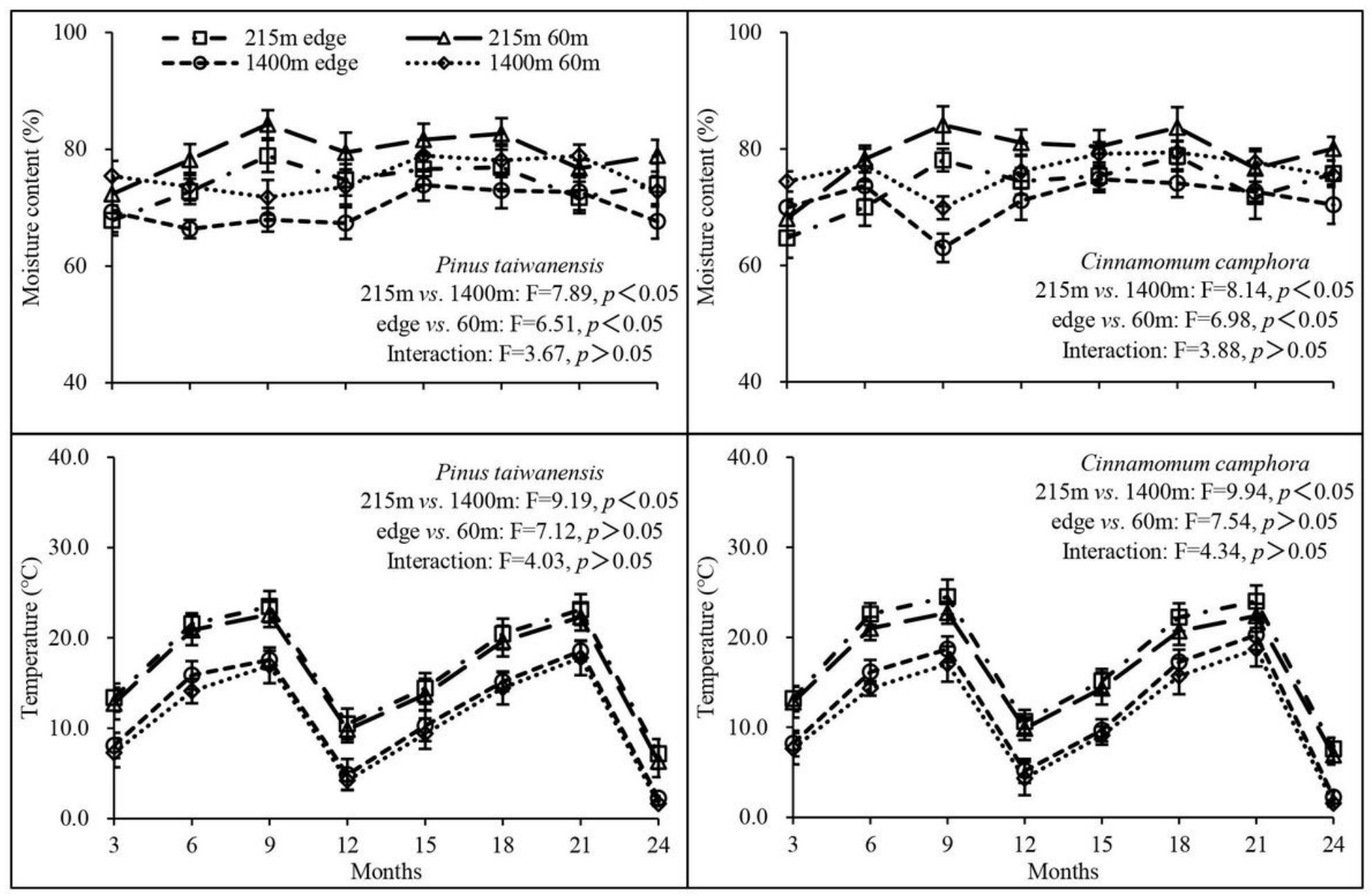

Figure 2

Temperature and moisture content of CWD of the two tree species at each altitude $(215 \mathrm{~m}$ and $1400 \mathrm{~m})$ and forest-edge distance (edge and $60 \mathrm{~m}$ from the forest edge) during the 24-month incubation. 


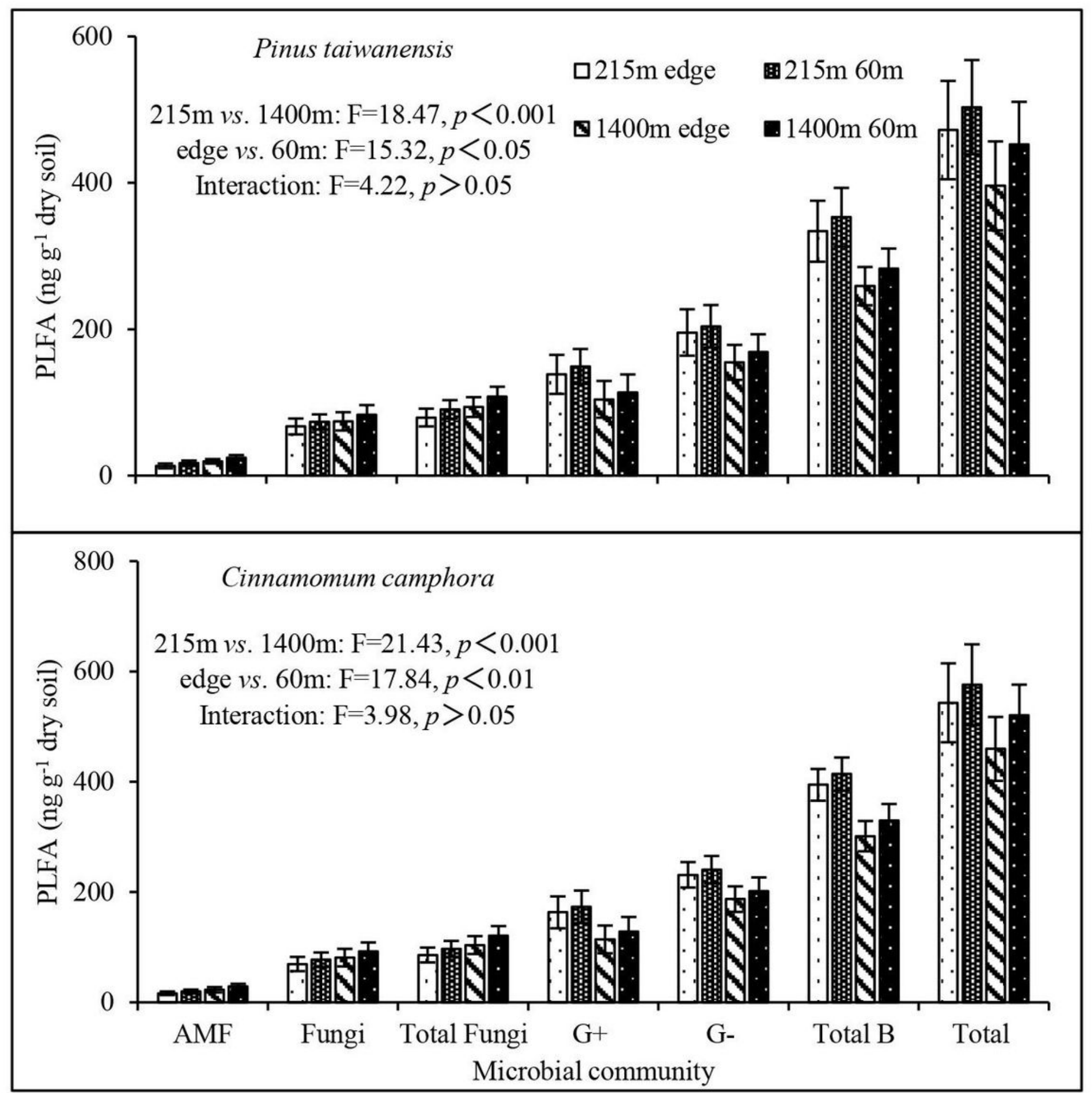

Figure 3

Soil phospholipid fatty acid (PLFA) (mean \pm SE; ng g-1 dry soil) signatures $(0-5 \mathrm{~cm})$ under CWD of the two tree species at each forest-edge distance (edge and $60 \mathrm{~m}$ from the forest edge) and altitude $(215 \mathrm{~m}$ and $1400 \mathrm{~m}$ ) in Lushan Mountain of subtropical China. Total, total PLFA concentrations; B, bacterial PLFAs; $F$, fungal PLFAs; F/B, fungal to bacterial ratio; G+, Gram-positive bacteria; G-, Gram-negative bacteria; G+/G-, ratio of Gram-positive to Gram-negative bacteria; AMF, arbuscular mycorrhizal fungi. 


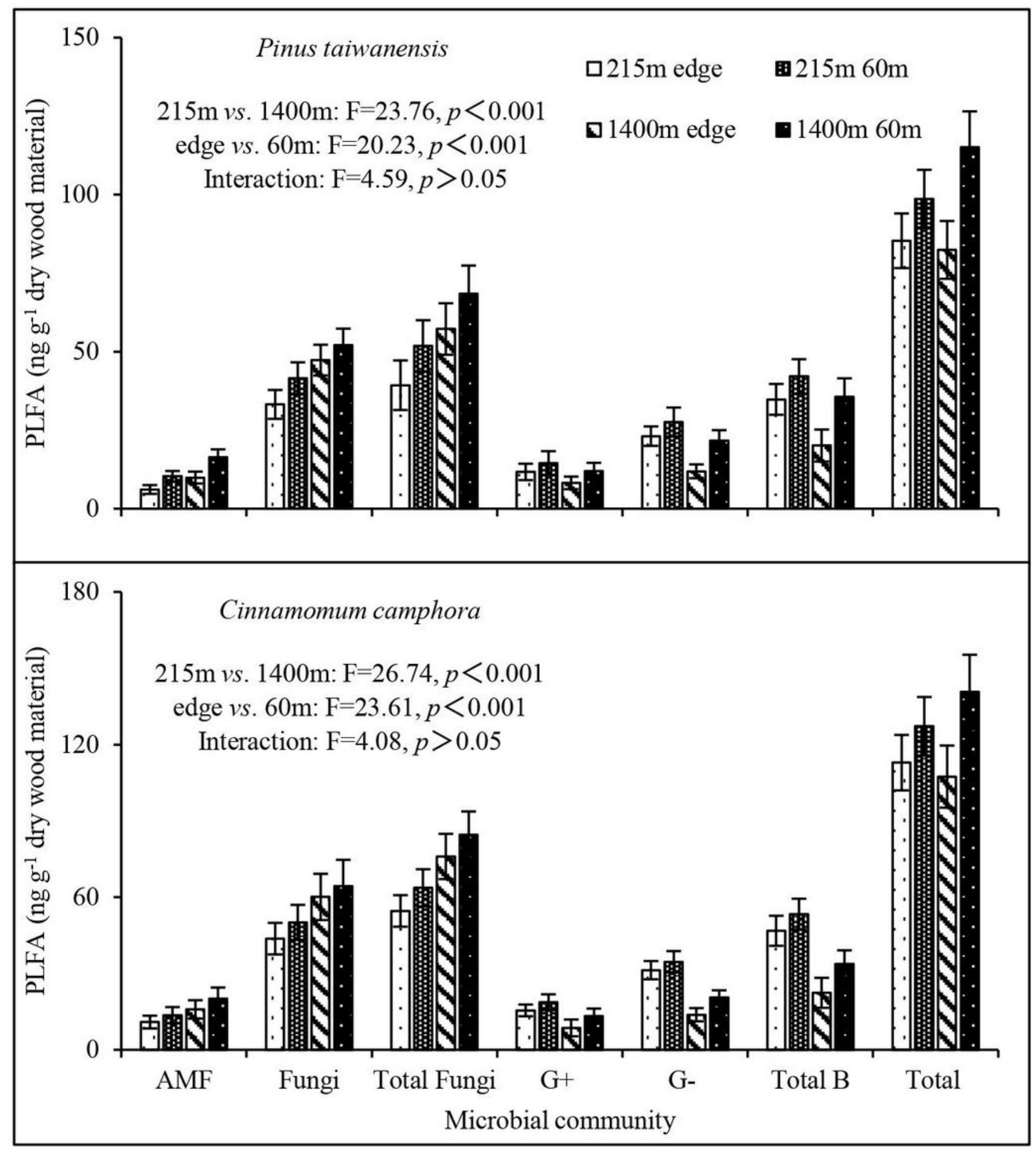

Figure 4

Phospholipid fatty acid (PLFA) (mean \pm SE; ng g-1 dry wood material) signatures of the CWD of the two tree species at each forest-edge distance (edge and $60 \mathrm{~m}$ from the forest edge) and altitude $(215 \mathrm{~m}$ and $1400 \mathrm{~m}$ ) in Lushan Mountain of subtropical China. Total, total PLFA concentrations; B, bacterial PLFAs; F, fungal PLFAs; F/B, the fungal to bacterial ratio; G+, Gram-positive bacteria; G-, Gram-negative bacteria; G+/G-, ratio of Gram-positive to Gram-negative bacteria; AMF, arbuscular mycorrhizal fungi. 